
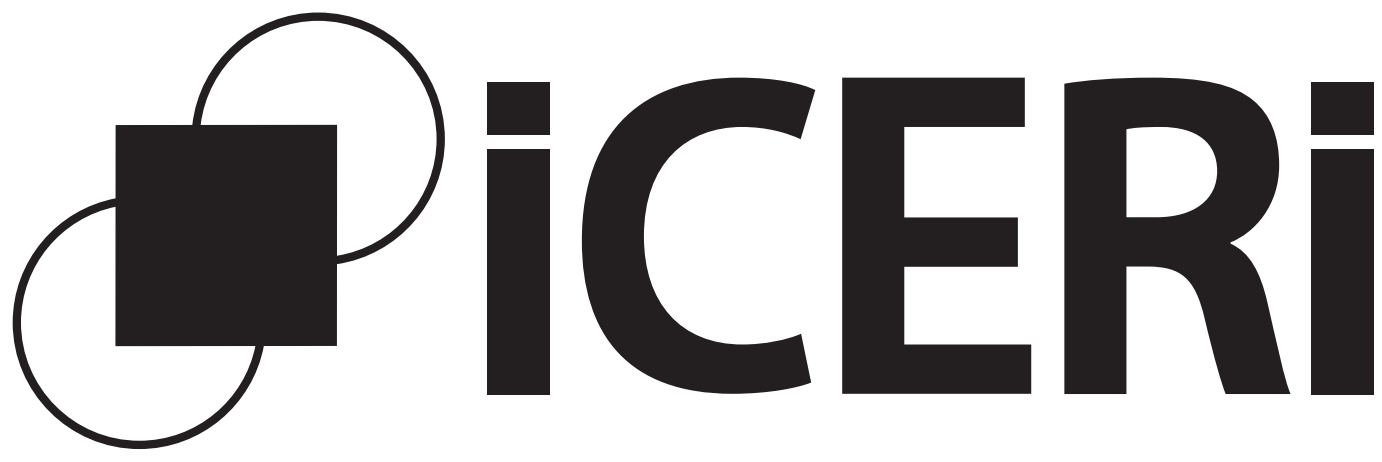

2020

13TH INTERNATIONAL CONFERENCE OF EDUCATION,

RESEARCH AND

INNOVATION
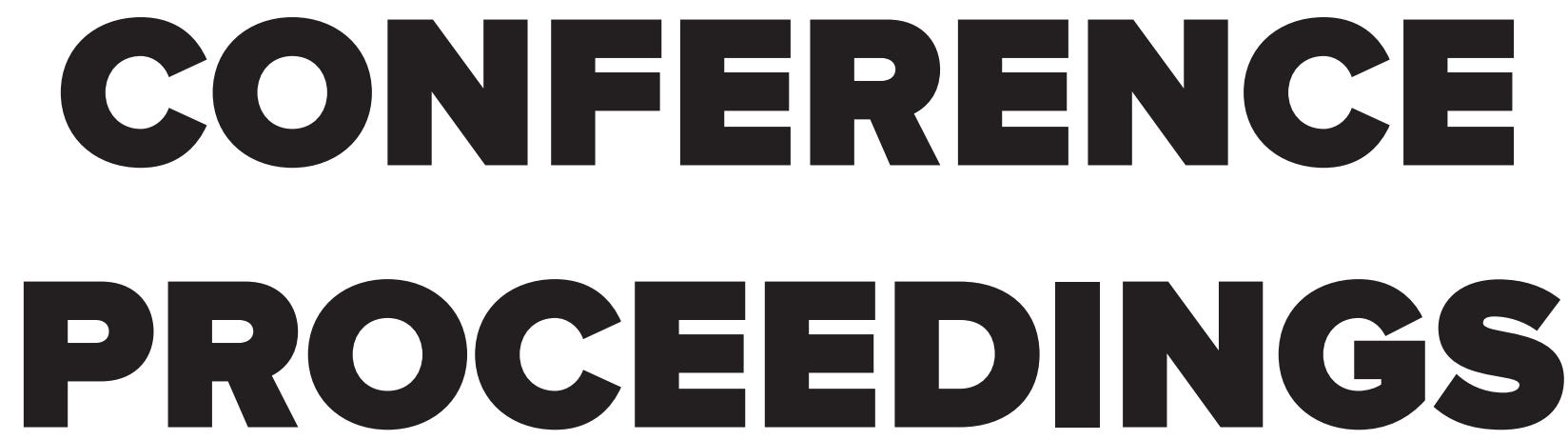

9-10 NOVEMBER 2020 iated.org/iceri 
Published by

IATED Academy

iated.org

\section{ICERI2020 Proceedings}

13th International Conference of Education, Research and Innovation

November 9th-10th, 2020

\section{Edited by}

L. Gómez Chova, A. López Martínez, I. Candel Torres

IATED Academy

ISBN: 978-84-09-24232-0

ISSN: $2340-1095$

V- 2372-2020

Book cover designed by

J.L. Bernat

All rights reserved. Copyright (C) 2020, IATED

The papers published in these proceedings reflect the views only of the authors. The publisher cannot be held responsible for the validity or use of the information therein contained. 


\title{
THE ROLE OF WORKERS' MOTIVATION AND COMMITMENT IN EDUCATIONAL MANAGEMENT: THE CASE OF A BRAZILIAN HIGHER EDUCATION INSTITUTION
}

\author{
S. Leal' ${ }^{1}$, J. Souza ${ }^{2}$ \\ ${ }^{1}$ Polytechnic Institute of Santarém \& Life Quality Research Centre (PORTUGAL) \\ ${ }^{2}$ Instituto Federal de Brasília (BRAZIL)
}

\begin{abstract}
This work investigates how the motivation and commitment of people at work influence the management of educational institutions. Additionally, the role of the manager in the context of school administration is also studied. To achieve the objectives of this work, the case study method was applied to a Brazilian public higher education institution (HEI).

The data were obtained through a questionnaire survey, which included three scales: (a) motivation for work, following Herzberg's conceptual framework; (b) organizational commitment, following Meyer and Allen's conceptual framework; and (c) management roles, following Mintzberg's conceptual framework. A sample of 61 workers was obtained, corresponding to $65 \%$ of the population of the higher education institution. Among all the respondents, $38(62 \%)$ were women, $31(51 \%)$ were under 40 years of age, $42(69 \%)$ were married, a large majority, $59(97 \%)$, had higher education qualifications, and $29(48 \%)$ were professors.

Regarding motivation at work, the professionals of the HEI studied feel professionally fulfilled, consider their work challenging and interesting, have professional growth, have been promoted, and have a good interpersonal relationship with the management. However, they do not feel that their work gives them status, nor do they feel that their work is recognized by managers. The three items that generates the greatest professional satisfaction are professional achievement, professional recognition, and salary.

Regarding organizational commitment, HEl employees have a high affective commitment, moderate normative commitment, and low continuance commitment. As far as the roles of the manager are concerned, the roles most frequently played are those of figurehead, liaison, disseminator, spokesperson, entrepreneur, resource allocator, and negotiator.
\end{abstract}

The case study carried out allowed to identify areas for improving the management of educational organizations, particularly in the human resources management domain. Clues for future research are also identified.

Keywords: Higher education institutions, motivation, commitment, Mintzberg's Management Roles.

\section{INTRODUCTION}

The motivation and commitment of people to work are crucial for organisations to achieve higher levels of performance. This is true for most organisations, and for higher education institutions (HEI) as well. The success of such organisations and the satisfaction of their clients (students) is strongly influenced by the motivation and commitment of both professors and non-teaching staff.

Studies show that there is a positive relationship between employee motivation and increasing the efficiency and effectiveness of organisations [1] or the organizational performance [2, 3]. Even though this is the desired result, the literature shows that "although employees in an organization are believed to work to achieve the assigned goals, not all employees are motivated to put the maximum efforts to get their jobs done" [2]. Thus, deepening knowledge about the levels of motivation or what motivates (or not) workers, particularly in HEls, is research worthy. "Most research and theory are built on the presumption that work motivation of individual employee will lead to greater performance at the aggregate level" [2]. This work will follow that assumption, and it will study the employee motivation from the individual-level perspective.

The literature also shows that organizational commitment is antecedent of job performance [4] and organizational citizenship behaviours [4,5], these results being more relevant for affective commitment [6]. Job performance and organizational citizenship behaviour are, in turn, significant antecedents of 
organizational performance and important variables that a manager should work with to improve it. The commitment of $\mathrm{HEl}$ employees is, then, worth of investigation.

All the antecedents of job performance and organizational performance could be handled by experienced managers. The manager's roles in the context of school administration are also studied. Mintzberg's conceptual framework of the manager's role will be considered [7].

This paper aims to investigate how the motivation and commitment of people at work influence the management of educational institutions. Additionally, the manager's role in the context of school administration is also studied. To achieve this purpose, the paper is organized into four sections. It starts with a very brief insight about the main concepts, followed by the methodological options made, it continues with the results, and ends with the conclusion.

\title{
2 THEORETICAL BACKGROUND
}

This section aims to review, with a very brief approach, the main theoretical concepts under study. The section starts with the motivation concept, then presents the organizational commitment construct, and finally, ends with the manager's role.

It is well recognized in the literature that "it is essential for an organization and its managers to understand what really motivates its employees if they intend to maximize organizational performance" [3]. There are several definitions and theories of motivation. Most of them are presented in the Lee and Raschke [3] article. In this article, the Motivation-Hygiene theory of Herzberg will be followed [8]. In the own words of Herzberg [8]:

\begin{abstract}
Motivation-hygiene theory suggests that job satisfaction and job dissatisfaction are produced by different factors. What makes people satisfied at work are factors that relate to the content of their jobs - specifically, achievement, recognition for achievement, interesting work, increased responsibility, growth, and advancement. On the other hand, what makes people unhappy at work is not what they do but how well (or poorly) they are treated. These treatment factors (dissatisfiers) are related not to the content of work, but to the context of the job. [8]
\end{abstract}

The satisfier factors are also known as motivators because if they are well developed, they can increase work motivation.

In what concerns organizational commitment, the best-known model is due to Meyer and Allen [6] and it considers a three-component conceptualization of organizational commitment: affective attachment to the organization (affective commitment), perceived costs associated with leaving the organization (continuance commitment), and obligation to remain with the organization (normative commitment). There are several antecedents and consequences of organizational commitment. For instance, some of the main consequences of affective commitment are lower turnover, lower absenteeism, lower stress at work, higher levels of job performance, and organizational citizenship behaviours $[4,5,6]$.

Higher levels of motivation and organizational commitment are desirable outcomes in any organization. For that, it is important that managers and leaders work with employees in a way that promotes an adequate organizational culture and good managerial practices. The study of Mintzberg's manager's roles is relevant in this process. For Mintzberg [7] any manager plays several roles that go far beyond the classic functions of planning, organising, directing, and controlling. Mintzberg [7] organized that roles in three groups: (a) interpersonal roles, embracing being figurehead, leader and promoting liaison; (b) informational roles, embracing being monitor, disseminator, and spokesperson; and (c) decisional roles, embracing being entrepreneur, disturbance handler, and resource allocator.

\section{METHODOLOGY}

In this section, the main methodological options are presented, namely the ones related to the sample and measures.

\subsection{Case study}

This work was carried out as a case study. The data were collected at a Brazilian HEI, the Federal Institute of Brasilia (FIB). FIB is an institution that has the legal nature of an autarky, belonging to the indirect administration of the Federal Government of Brazil, linked to the Ministry of Education, and its 
main activity is to provide higher, basic and professional education. It has administrative, patrimonial, financial, didactic, pedagogical, and disciplinary autonomy. FIB is organised in ten campi and one rectory. The study was performed in the Planaltina campus, which is composed of 112 permanent workers ( $56 \%$ professors and $44 \%$ non-teaching staff).

\subsection{Sample}

At the time of the study, from the 112 employees, 18 were on leave for various reasons (e.g., qualification, illness, maternity). The questionnaire was, then, administered to $94 \mathrm{HEl}$ employees, of which, 61 participated in the study (65\% response rate). The employees in the sample were $62 \%$ females (n:38), 51\% had less than 40 years old (n:31), 69\% were married (n:42), 97\% had at least a degree (n:59), and $72 \%$ worked for the HEl for less than 10 years (n:46).

\subsection{Measures}

The data were obtained through a survey. The survey has three measures. The first is a motivation for the work scale following Herzberg's conceptual framework [8]. This scale was developed by Souza in their Master thesis work [9] and has 16 items, six for the motivators factor, and ten for the hygiene factor [8]. Respondents could respond on a Likert scale of 5 points (1: I totally disagree, 2: I disagree, 3: I neither agree nor disagree, 4 : I agree, 5: I totally agree). One example of the item is: I feel professionally fulfilled with the work I do.

The second measure is the organizational commitment scale - following Meyer and Allen's conceptual framework [6] - developed by Rego et al. [10]. The scale has 11 items to assess the affective, normative, and continuance commitment dimensions. The scale was validated by Rego et al. [10] in the Portuguese and Brazilian context. As in Rego et al. [10], each individual was asked to mark, on a seven-point scale, the degree to which the affirmation applied to him (1: The affirmation does not apply to me at all; 7: The affirmation applies to me completely). One example of the item is: "I am proud to tell others that I am part of this organisation".

The third measure aims to assess the manager's roles following Mintzberg's conceptual framework [7]. This scale was developed by Souza in their Master thesis work [9] and has twenty items, two for each Mintzberg's manager role. Individuals were asked to indicate their agreement with the statements on a Likert scale of 5 points (1: I totally disagree, 2: I disagree, 3: I neither agree nor disagree, 4: I agree, 5: I totally agree). One example of the item is: "Your direct manager can give and receive feedback".

\section{RESULTS}

Following a descriptive approach, this section presents the main results, organized in three subsections: motivation, organizational commitment, and manager's roles.

\subsection{Motivation}

Most HEl employees score highly on Herzberg's motivational factors (Table 1). Most of the employees feel professionally fulfilled with the work they do (70\%), find their work challenging and interesting $(74 \%)$, feel responsible for the work they do $(95 \%)$, have promotion opportunities $(70 \%)$, and have professional growth (61\%). Notwithstanding, only $46 \%$ considered themselves recognised for the work they do.

Hygienic factors show slightly lower levels of agreement than motivational factors. The results suggest that: they consider their interpersonal relationship with the leadership to be good (87\%), they are satisfied with the remuneration (56\%), they consider the interpersonal relationship with other servers to be good $(80 \%)$, they consider the reconciliation between personal and professional life satisfactory $(61 \%)$, they consider the management's interpersonal relationship with them to be good ( $87 \%)$, they feel secure in their public office $(59 \%)$. However, only $43 \%$ agree that the organisation's policies and administration are satisfactory, $46 \%$ agree that the supervision received from the hierarchical superior is effective, $49 \%$ agree that the physical condition of the working environment is good, and $31 \%$ agree that their work gives them status. 
Table 1. Motivation results.

\begin{tabular}{|c|c|c|c|c|}
\hline & & $\begin{array}{l}\text { Disagreement } \\
\qquad(1+2)\end{array}$ & $\begin{array}{c}\text { Neutral } \\
\text { (3) }\end{array}$ & $\begin{array}{c}\text { Agreement } \\
(4+5)\end{array}$ \\
\hline \multicolumn{5}{|c|}{ Motivators factor } \\
\hline 1 & I feel professionally fulfilled with the work I do & $16 \%$ & $14 \%$ & $70 \%$ \\
\hline 2 & I consider myself recognised for the work I do & $34 \%$ & $20 \%$ & $46 \%$ \\
\hline 3 & I find my work challenging and interesting & $11 \%$ & $15 \%$ & $74 \%$ \\
\hline 4 & I feel responsible for the work I do & $3 \%$ & $2 \%$ & $95 \%$ \\
\hline 5 & I have promotion in my professional career & $20 \%$ & $10 \%$ & $70 \%$ \\
\hline 6 & I have professional growth & $25 \%$ & $14 \%$ & $61 \%$ \\
\hline \multicolumn{5}{|c|}{ Hygiene factor } \\
\hline 7 & The organisation's policies and administration are satisfactory & $39 \%$ & $18 \%$ & $43 \%$ \\
\hline 8 & I consider the supervision received from the hierarchical superior to be effective & $30 \%$ & $24 \%$ & $46 \%$ \\
\hline 9 & I consider my interpersonal relationship with the leadership to be good & $10 \%$ & $3 \%$ & $87 \%$ \\
\hline 10 & I consider the physical condition of the working environment to be good & $25 \%$ & $26 \%$ & $49 \%$ \\
\hline 11 & I am satisfied with my remuneration & $36 \%$ & $8 \%$ & $56 \%$ \\
\hline 12 & I consider the interpersonal relationship with other servers to be good & $8 \%$ & $12 \%$ & $80 \%$ \\
\hline 13 & I consider the reconciliation between personal and professional life satisfactory & $25 \%$ & $14 \%$ & $61 \%$ \\
\hline 14 & I consider the management's interpersonal relationship with me to be good & $10 \%$ & $3 \%$ & $87 \%$ \\
\hline 15 & I feel that my work gives me status & $39 \%$ & $30 \%$ & $31 \%$ \\
\hline 16 & I feel secure in my public office & $15 \%$ & $26 \%$ & $59 \%$ \\
\hline
\end{tabular}

The results suggest that the HEI can introduce measures to improve recognition for the work the employee does, to develop the company's management policies, to enhance supervision, and to strengthen employee status levels.

\subsection{Organizational commitment}

Responses on organisational commitment (Table 2) show that HEl employees understudy show high levels of affective commitment (percentage of agreement in items 1, 2, and 3 ranging from $48 \%$ to $70 \%$ ), moderate/low levels of normative commitment (percentage of disagreement in items 4,5 and 6 ranging from $44 \%$ to $64 \%$ ) and low levels of continuance commitment (percentage of disagreement in items 7 to 11 ranging from $65 \%$ to $75 \%$ ).

Table 2. Organizational commitment results.

\begin{tabular}{|c|c|c|c|c|}
\hline & & $\begin{array}{l}\text { Disagreement } \\
(1+2+3)\end{array}$ & $\begin{array}{l}\text { Neutral } \\
\text { (4) }\end{array}$ & $\begin{array}{l}\text { Agreement } \\
(5+6+7)\end{array}$ \\
\hline \multicolumn{5}{|c|}{ Affective commitment } \\
\hline 1 & I am proud to tell others that I am part of this organisation & $8 \%$ & $23 \%$ & $69 \%$ \\
\hline 2 & I have a strong sympathetic attachment to this organisation & $7 \%$ & $23 \%$ & $70 \%$ \\
\hline 3 & I feel "part of the family" of my organisation & $26 \%$ & $26 \%$ & $48 \%$ \\
\hline \multicolumn{5}{|c|}{ Normative commitment } \\
\hline & $\begin{array}{l}\text { Even if it would bring me advantages, I feel I should not leave my organisation } \\
\text { now }\end{array}$ & $44 \%$ & $15 \%$ & $41 \%$ \\
\hline & $\begin{array}{l}\text { I would not leave my organisation now because I feel an obligation to the } \\
\text { people who work here }\end{array}$ & $54 \%$ & $12 \%$ & $34 \%$ \\
\hline 6 & $\begin{array}{l}\text { I feel that if I received an offer for a better job, it would not be right to leave my } \\
\text { organisation }\end{array}$ & $64 \%$ & $15 \%$ & $21 \%$ \\
\hline
\end{tabular}




\begin{tabular}{llll}
\hline Continuance commitment & & \\
\hline $7 \quad \begin{array}{l}\text { I stay in this organisation because I feel I couldn't easily join another } \\
\text { organisation }\end{array}$ & $66 \%$ & $13 \%$ & $21 \%$ \\
\hline $8 \quad \begin{array}{l}\text { I remain in this organisation because, if I left, I would have to make great } \\
\text { personal sacrifices }\end{array}$ & $65 \%$ & $10 \%$ & $25 \%$ \\
\hline $9 \quad$ I feel I have few alternatives for employment if I leave this organisation & $69 \%$ & $11 \%$ & $20 \%$ \\
\hline $\begin{array}{l}10 \text { I stay in this organisation because I feel that I have few opportunities in other } \\
\text { organisations }\end{array}$ & $75 \%$ & $9 \%$ & $16 \%$ \\
\hline 11 I will not leave this organisation because of the losses that would harm me & $66 \%$ & $8 \%$ & $26 \%$ \\
\hline \hline
\end{tabular}

Literature provides "support for the proposition that the three components of commitment have different implications for work-related behaviour" [11]. For instance, whereas the affective commitment correlated positively with the supervisor's ratings of job performance, continuance commitment correlated negatively [11]. Then, the results obtained in this HEI are aligned with literature and were expected.

\subsection{Manager's roles}

The last section of the paper studies the manager's roles (Table 3) from the employees' point of view. $\mathrm{HEI}$ employees agree that their direct managers play most of the management roles advocated by Mintzberg [7]. The roles most frequently played by managers are figurehead ( $82 \%$ agreement), negotiator (73\% agreement), liaison (63\% agreement), disseminator (61\% agreement), resource allocator (57\% agreement), entrepreneur (55\% agreement), and spokesperson (54\% agreement). The less frequently adopted roles are that of a monitor (38\% agreement) and disturbance handler $(40 \%$ agreement).

Table 3. Manager's roles results.

\begin{tabular}{|c|c|c|c|c|}
\hline & & Disagreement (1+2) & Neutral (3) & Agreement (4+5) \\
\hline \multicolumn{5}{|c|}{ Interpersonal roles } \\
\hline 1 & Figurehead & $9 \%$ & $9 \%$ & $82 \%$ \\
\hline 2 & Leader & $19 \%$ & $32 \%$ & $49 \%$ \\
\hline 3 & Liaison & $15 \%$ & $22 \%$ & $63 \%$ \\
\hline \multicolumn{5}{|c|}{ Informational roles } \\
\hline 4 & Monitor & $33 \%$ & $29 \%$ & $38 \%$ \\
\hline 5 & Disseminator & $11 \%$ & $28 \%$ & $61 \%$ \\
\hline 6 & Spokesperson & $11 \%$ & $35 \%$ & $54 \%$ \\
\hline \multicolumn{5}{|c|}{ Decisional Roles } \\
\hline 7 & Entrepreneur & $20 \%$ & $25 \%$ & $55 \%$ \\
\hline 8 & Disturbance handler & $13 \%$ & $47 \%$ & $40 \%$ \\
\hline 9 & Resource allocator & $14 \%$ & $29 \%$ & $57 \%$ \\
\hline 10 & Negotiator & $9 \%$ & $18 \%$ & $73 \%$ \\
\hline
\end{tabular}

\section{CONCLUSIONS}

Regarding motivation at work, the professionals of the HEl feel professionally fulfilled, consider their work challenging and interesting, have professional growth and have been promoted, and have a good interpersonal relationship with the management. However, they do not feel that their work gives them status, nor do they feel that their work is recognized by managers. The three items that generate the greatest professional satisfaction are professional achievement, professional recognition, and salary.

Regarding organizational commitment, $\mathrm{HEl}$ employees have a high affective commitment, moderate normative commitment, and low continuance commitment. As far as the roles of the manager are concerned, the roles most frequently played are those of figurehead, liaison, disseminator, spokesperson, entrepreneur, resource allocator, and negotiator. 
The management of educational organizations can use these results to improve management practices. For instance, the analysis of the motivation results reveals areas of improvement like to increase the perceived status that the work provided by each employee, or to improve the organizational policies and the administration of the HEl. The HEI has employees highly committed, at least affectively, and this result leads us to suggest that they are available to contribute to a more efficient and effective organisation. The institution has direct managers that have the skills and abilities to motivate and to increase the commitment of the employees, at least when the analysis takes into consideration the managers' role. We can highlight the roles of being a negotiator and to be able to promote the liaison between human resources.

Notwithstanding, this is just a descriptive study and no relationship between variables was tested. Future studies could test if higher levels of motivation result in higher levels of commitment (preferable the affective commitment), as well as if this relation is moderated by the manager's roles. Moreover, the results presented are specific of an HEl organization, and future studies should embrace more HEls.

\section{ACKNOWLEDGEMENTS}

The first author acknowledge support from Centro de Investigação em Qualidade de Vida (Life Quality Research Centre).

\section{REFERENCES}

[1] I. Oncioiu, M. Petrescu, M. C. Duicã \& G. Croitoru, "The Impact of Employee Motivation on Romanian Organizational Performance", Information Resources Management Journal, vol. 31, no. 4, pp. 59-74, 2018. doi:10.4018/IRMJ.2018100104

[2] H.-W. Lee, "How Does Sustainability-Oriented Human Resource Management Work?: Examining Mediators on Organizational Performance", International Journal of Public Administration, vol. 42, no. 11, pp. 974-984, 2019. doi:10.1080/01900692.2019.1568459

[3] M. T. Lee \& R. L. Raschke, "Understanding employee motivation and organizational performance: Arguments for a set-theoretic approach", Journal of Innovation \& Knowledge, vol. 1, no. 3, pp. 162169, 2016. doi:10.1016/j.jik.2016.01.004

[4] M. Riketta, "Attitudinal organizational commitment and job performance: a meta-analysis", Journal of Organizational Behavior, vol. 23, no. 3, pp. 257-266, 2002. doi:10.1002/job.141

[5] J. P. Meyer, D. J. Stanley, L. Herscovitch \& L. Topolnytsky, "Affective, continuance, and normative commitment to the organization: A meta-analysis of antecedents, correlates, and consequences", Journal of Vocational Behavior, vol. 61, pp. 20-52, 2002.

[6] J. P. Meyer \& N. J. Allen, Commitment in the Workplace: Theory, Research and Application. Thousand Oaks, California: Sage Publications, 1997.

[7] H. Mintzberg, "The Manager's Job: Folklore and Fact", Harvard Business Review, vol. 68, no.2, 163176, 1990

[8] F. Herzberg, "Motivation-Hygiene Profiles: Pinpointing What Ails The Organization". Organizational Dynamics, vol. 3, no.2, pp. 18-29, 1974. doi:10.1016/0090-2616(74)90007-2

[9] J. Souza, Motivação para o trabalho e comprometimento organizacional no serviço público: um estudo de caso, Trabalho de Projeto apresentado para obtenção de grau de Mestre no âmbito do Mestrado em Ciências da Educação/Administração Educacional da Escola Superior de Educação do Instituto Politécnico de Santarém, 2020. https://repositorio.ipsantarem.pt/bitstream/ 10400.15/3022/1/DISSERTA\%C3\%87\%C3\%83O_Jovita\%20Santos\%20Souza_FINAL.pdf

[10] A. Rego, M.P. Cunha \& S. Souto, "Espiritualidade nas organizações e comprometimento organizacional", RAE - Eletrónica, vol. 6, no. 2, pp. 1-27, 2007.

https://rae.fgv.br/sites/rae.fgv.br/files/artigos/10.1590_S1676-56482007000200003.pdf

[11] J. P. Meyer \& N. J. Allen, "A three-component conceptualization of organizational commitment", Human Resource Management Review, vol. 1, no. 11, pp. 61-89, 1991. 